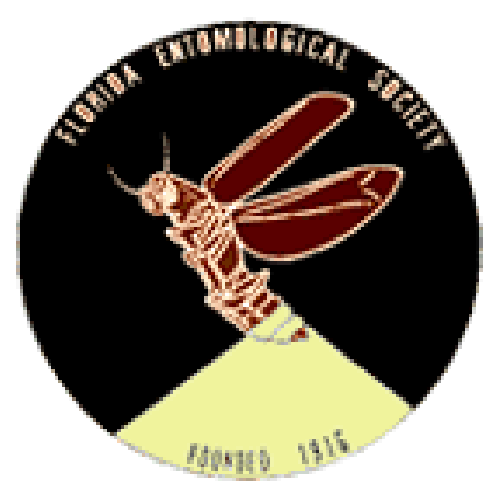

Traps for Collecting Live Euphasiopteryx depleta (Diptera: Tachinidae) at a Sound Source Author(s): H. G. Fowler

Source: The Florida Entomologist, Vol. 71, No. 4 (Dec., 1988), pp. 654-656

Published by: Florida Entomological Society

Stable URL: http://www.jstor.org/stable/3495023

Accessed: 15/01/2014 08:54

Your use of the JSTOR archive indicates your acceptance of the Terms \& Conditions of Use, available at http://www.jstor.org/page/info/about/policies/terms.jsp

JSTOR is a not-for-profit service that helps scholars, researchers, and students discover, use, and build upon a wide range of content in a trusted digital archive. We use information technology and tools to increase productivity and facilitate new forms of scholarship. For more information about JSTOR, please contact support@ jstor.org.

Florida Entomological Society is collaborating with JSTOR to digitize, preserve and extend access to The Florida Entomologist. 


\title{
SCIENTIFIC NOTES \\ TRAPS FOR COLLECTING LIVE \\ EUPHASIOPTERYX DEPLETA (DIPTERA: TACHINIDAE) AT A SOUND SOURCE
}

\author{
H. G. FowLER \\ Instituto de Biociencias, Universidade Estadual Paulista \\ UNESP, 13500 Rio Claro, S Paulo, Brazil, and (formerly) \\ Entomology \& Nematology Department, 3103 McCarty Hall, \\ University of Florida, Gainesville, Florida 32611, U.S.A.
}

After Wolcott (1940) reported rearing the tachinid Euphasiopteryx depleta (Wied.) from a Scapteriscus mole cricket (Orthoptera: Gryllotalpidae), interest has been shown in using this fly in introductions for the biological control of Scapteriscus. Fowler and Kochalka (1985) reported attracting $E$. depleta to the synthesized broadcast calls of $S$. acletus Rehn \& Hebard in Paraguay. Using similar synthesizers (Walker 1982), Fowler and Garcia (1987) reported additional captures of $E$. depleta, and of rearing it from $S$. acletus, S. vicinus Scudder and S. abbreviatus Scudder. In those studies, attracted female $E$. depleta were captured with an aerial net over the synthesizer and larvae taken from them were placed on mole crickets to achieve laboratory parasitism. Subsequently, aerial nets were replaced with a sheet of plastic covered with Tanglefoot ${ }^{\circledR}$, and large numbers of female $E$. depleta were obtained. However, in the laboratory, often the Tanglefoot would interfere with obtaining larvae, as many were killed in the female's body through asphyxiation, or were gummed and died as they left the female's body. Also, for some laboratory studies, healthy, gravid females were needed, which could not be obtained by sticky trapping. Using flashlights and aerial nets to capture females at sound synthesizers was not highly productive, as $E$. depleta tended to avoid lighted areas.

To overcome these problems, two traps were designed and field tested (Fig. 1). Both traps were inexpensive, consisting of a wire frame, with muslin sides and funnels, which were used to direct flies into the trap. Cardboard baffles mounted on wire were used to hinder fly escape after capture (Fig. 1). The muslin base was built so that the trap could easily fit over a sound synthesizer (Walker 1982) or over a tape player.

Trap designs were evaluated by comparison of the numbers of flies caught in each with the numbers caught on sticky traps. In December 1984, three sound synthesizers broadcasting S. vicinus songs were placed in the field in Rio Claro, state of São Paulo, Brazil. One synthesizer was fitted with sticky plastic sheeting, and the other two with the two trap designs. After each night, the location of each was switched. Each synthesizer was separated by $30 \mathrm{~m}$ from its neighbor. The sticky trap caught 132 flies during 2 weeks of trapping. Trap B, fitted with 5 funnels, of which 4 were lateral, was about 2.5 times as efficient as design A, consisting of only 1 funnel (Fig. 1). Trap B was about a third as efficient as the sticky trap.

Field observations indicated that flies alighted on the muslin and walked extensively over the trap's external surface until they were channeled into its interior through the funnels. Many flies departed without ever reaching the trap's interior. This explains why the numbers of female $E$. depleta caught in the traps were much less than with sticky traps. If large numbers of flies are required, sticky traps should be used. If, however, viable healthy females are required, then trap design B should be used. Sticky traps are recommended for population monitoring.

I thank Joāo Justi and Madelena Lima Costa for their assistance with the field portion of this project. This study was funded in part by a grant, USDA No. 83-CRSR-2- 
A

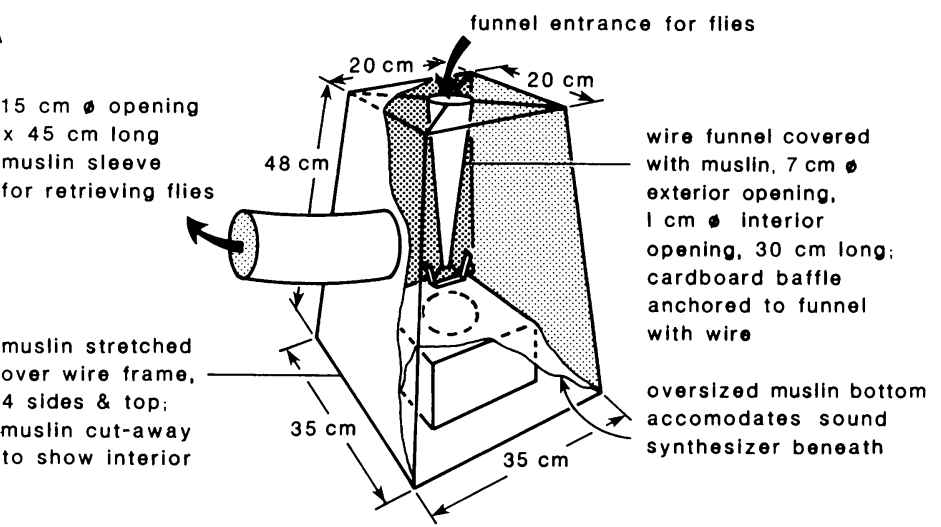

B

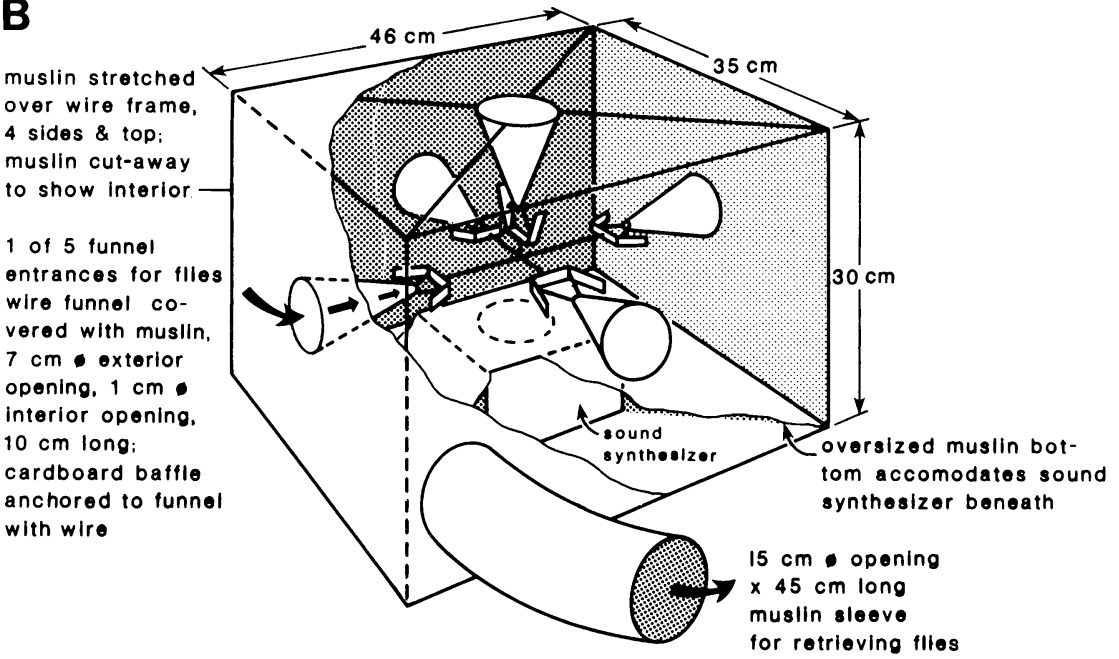

Fig. 1. Trap designs evaluated for live captures of healthy $E$. depleta females. Frames of both are of wire, and sides and funnels of muslin. Note how trap base sits over a sound trap. Baffles are made of cardboard and wire, and mounted over funnels.

2162. I thank J. H. Frank and T. J. Walker for their interest and comments on the manuscript, and Susan Wineriter for drawing Fig. 1. University of Florida, Institute of Food \& Agricultural Sciences, journal series No. 8708.

\section{REFERENCES Cited}

Fowler, H. G., AND C. R. Garcia. 1987. Attraction to synthesized songs and experimental and natural parasitism of Scapteriscus mole crickets (Orthoptera: Gryllotalpidae) by Euphasiopteryx depleta (Diptera: Tachinidae). Rev. Brasileira Biol. 47: 371-74. 
Fowler, H. G., AND J. A. Kochalka. 1985. New record of Euphasiopteryx depleta (Diptera: Tachinidae) from Paraguay: attraction to broadcast calls of Scapteriscus acletus (Orthoptera: Gryllotalpidae). Florida Ent. 68: 225-26.

$\rightarrow$ WALKeR, T. J. 1982. Sound traps for sampling mole cricket flights (Orthoptera: Gryllotalpidae: Scapteriscus). Florida Ent. 65: 105-10.

WolcotT, G. N. 1940. A tachinid parasite of the Puerto Rican changa. J. Econ. Ent. 33: 202.

\title{
DIFFERENTIAL INJURY BY LESSER CORNSTALK BORER (LEPIDOPTERA: PYRALIDAE) IN SOYBEANS OF DIFFERENT GROWTH STAGES
}

\author{
L. B. BRAXTON \\ Senior Research Biologist Agricultural Products Department \\ Dow Chemical U.S.A., 510u W. Kennedy Boulevard, Suite 450 \\ Tampa, FL 33609 USA \\ AND \\ M. E. GiLREATH \\ North Florida Research and Education Center \\ University of Florida, IFAS \\ Quincy, FL 32351 USA
}

The lesser cornstalk borer (LCB), Elasmopalpus lignosellus (Zeller), has been ranked one of the top four insect pests of soybean in Florida every year for the last four years, with crop losses estimated as high as \$1.7MM (Sprenkel 1984, 1985, 1986, 1987). Damage by LCB to soybeans is usually restricted to the period from plant emergence through the early vegetative stages (Todd \& Suber 1988). Although other stages may be attacked, seedling soybeans are most susceptible to injury (Isley \& Miner 1944). Our observations indicate a growth differential of only seven days can substantially affect the extent of damage incurred by lesser cornstalk borer larvae.

Observations were made in a 40 -acre field of 'Centennial' soybeans in Jackson County, Florida. Approximately half the field had been planted June 19, 1987, and the other half June 26. Both plantings were adjacent to corn, which was nearing maturity about the time the soybeans were planted. Initial observations were made August 3. The younger side of the soybean field was noted to have a poor stand; many dead plants were present and several large LCB larvae were seen crawling on the soil surface near the plant bases. No larvae and few damaged plants were observed in the older soybeans. Numerous adults were flushed throughout the field.

Additional observations were made four days later. At that time, percent damaged plants was determind for each side of the field by sampling five adjacent plants at each of 20 randomly selected sites (100 total plants per side). Plants were unearthed with a trowel and inspected for larvae or characteristic LCB damage, as evidenced by visible stalk boring or stem feeding near the plant base, sometimes accompanied by a silken feeding tube. Slightly damaged plants exhibited varying degrees of stunting and chlorosis, while many heavily damaged plants were dead and had a characteristic brown teepee-shaped appearance (Herbert \& Mack 1987). 